DOI https://doi.org/10.18551/rjoas.2018-12.41

\title{
EARLY DETECTION TO INTERCEPT TERRORISM CIVIL LAW VIOLATION BY EX-TERRORIST PRISONERS
}

\author{
Situmorang Trifonia* \\ Master of Police Science, Postgraduate School, University of Airlangga, Indonesia \\ *E-mail: situmorangtrifonia@gmail.com
}

\begin{abstract}
There is some behaviour of the prisoners that need to be watched by officers, those are marked with the radical behaviours that still become their ideology. The behaviours may lead to trigger some anarchism event during their serve in jail. Moreover, the ability to craft boom must be specially watched as there will be many people to learn how to craft it from them. Next, the analysis on mental condition of these people stated that the suspect who are trapped in terrorism ideology, even in some cases they are willing to do suicide bombing, are not psychopath. But, it is the result of their forced ideology as they have no something to hold on previously on their life. Next conclusion is the behaviour of ex prisoners who tend to repeat the action which is marked by introvert behaviour, the continuing interaction between ex terrorist prisoners, the continuing affiliation between prisoners and radical group, low nationalism, and the inability for society to embrace the ex terrorists.
\end{abstract}

\section{KEY WORDS}

Early detection, intercept terrorism, ex-terrorist prisoners.

Terrorism is one of crime that uses violation shows different character and form with another crime. According to Thomas Santoso, terrorism is not a violation act, but it is a political method that uses violation. Terrorist does not see violation as their ultimate goal, but it is a way for them to showing of power and it is effective way to show intimidation to their enemies (Thomas Santoso: 2002: 20)

From several cases, the terrorism actions in Indonesia are committed by ex terrorist prisoners. Yayat Cahdiyat, he is a terrorist in pressure cooker bomb occurred in Bandung city, he is also an ex terrorist prisoners. Other cases which are committed by ex prisoners are Molotov bombing anarchy in front of Oikumene Church 003 Neighbourhood number 32 of cipto mangun kusumo street Sengkotek Village, Loa Janan llir District, Samarinda, East Kalimantan. The action was committed by Juhanda on November 13 of 2016 results in child with burned injury. The police had confirmed that the Molotov bombing suspect is an exprisoners of Puspitek Serpong which is a member of Pepy Virdano radical. After the suspect served his time in jail, he joint JAD group which is linked to Anshori group in eastern java. The group was continuously watched by the police as it has detected to illegally import some weapons from Philippine (Tamat Suryani, 2 November 2017: 286).

\section{METHODS OF RESEARCH}

The Research approach used in this study is The juridical empiric. In other word, it is sociology law study and could be determined as field observation research by examining the recent law applied to society and how it affects them (Suharsimi Arikunto, 2002: 126).

This research used the discriptive qualitative to describe the current regulation and situation. The attempt are by describing, note taking, analysing, and interpreting the current condition. In other word, the descriptive qualitative aims to collect the current information among people (Mardalis, 1999: 26).

In order to collect the data, researcher uses some sources which are: The Intelligent council Director of Regional Police of East Java, The member of Intelligent council of Regional Police of East Java, The ex-terrorist prisoner. Data Collection Technique to analyse the data used some methods, there are: (1) Observation. It is the core of all knowledge. The researcher could only work based on data, it is the fact occurred in this world which is gathered by observation. (2) Interview. It is a dialogue within special aim, the interview 
process must be done between interviewer which commence questions and responded by interviewee. (3) Documentation. It is the activity to gather some documents as source of data information based on the research problem such as map, statistic, finance report, biography, citizens data, graphic, picture, mails, photo, etc. (4) It is an examination performed by researcher by collecting some books, magazine, pamphlet, leaflet, which can be used to support the study.

\section{DISCUSSION OF RESULTS}

The implementation of early detection to intercept terrorism by ex terrorist prisoners has some method, there are:

First, Intelligent council Police Early Detection Method. About early detection of investigation toward identification and other source of crime especially for the crimes that possessed high threat such as terrorism, the investigation may be applied based on intelligent phase cycle, the phases are as follow: a) Preparation Phase, Forming the formula of Main Element Information, the investigation plan consist of: determine the most possible problem, assume the possibilities, determine the action method and conduct it on operational type, create main element information list, justify them and must get the answer from intelligent council, determine the answer and the most possible answer which has three minimum answers, the name must be synchronised with the council, they are $(R=$ Regular, $A=$ Alternative, $E=$ Emergency), determine the time limit and gathering point.

Second, The Seek/Gather Process. It is an act of gathering some information based on the command of authorised leader. The collecting information technique may apply several ways both closed and opened technique. There are several techniques in collecting information which are observation, interview, interrogation, examination, description, tracking, hearing, infiltration, tapping, and trapping.

Third, Cultivation Phase. It is an act to produce intelligent product from the data and information that are already gathered before. The phases of cultivating process are: Note taking, it must be performed systematically and chronologically toward evidence. Thus, the information is quick to be learned. The simplified data is very efficient to be stored if it is needed in future time; Assessing, the source of information must be reliable. Thus, it needs to be measured about the loyalty of the man. By using assessment balance, the data taken from them is determined whether it is a valid data or not; Interpreting, it is determining the meaning of one evidence to another. The interpreting process uses comparison, confirmation. The new evidence is received within the previous one. Stated in article 21 of PKBIK, it states that interpreting must use defining phase (the formation of idea and concept), determination phase, and logical phase or conclusion; Displaying Phase. The intelligent product must be sent directly to the exact time and place. The displaying product phase must consider several points, there are: will the product be useful in future days ?, Is the product useful for upper, side, and bottom council? In serving the information, the model and technique are varies depend on the urgency, classified, quick, precision, and safety of the data.

There are several problems while implementing early detection program by intelligent council personnel of Surabaya Police Officer, which are mentioned below:

First, internal Factor among intelligent council personnel. There are several organisation internal factors that become obstacle in early detection especially in detecting the ex terrorist prisoner, they are as follow: (a) The personnel problem or human error. According to the research observation, the human resource problem is coming from the low rate of interest for people to take a part in this division. The interest to join the division is too low even among Indonesian police personnel. Because, the pride of the division is not as high as another division such as Detective Crime Federal or Traffic Division. By this situation, the formation of police at lowest level such as Sector police, the intelligent division does not have pure personnel who master in intelligent skill. in contrast, it takes very special skill to perform early detection on such extra ordinary crime such as terrorism. (b) The finance problem. In order to improve the early detection role among intelligent council division of eastern java jurisdiction, there must be more supply of the financial aid that could be self managed by DIPA. Thus, the obstacle of personnel during their duty will be minimised. For 
example, in 2018 , one of sector police only received 500.000 rupiahs for three months operation which is allocated for three personnel. The low aid from financial perspective may result in unclassified information, the response in collecting information become slower. (c) the lack of coordination between Intelligent council and Densus 88 intelligent. The coordination is very important between personnel from different division. The lack of coordination between them results in ineffective duty. Seen from the duty direction, those two divisions must perform horizontal coordination. This kind of coordination aims to unification and commandment which is performed between same level organisations.

Second, The changing attack pattern by terrorist. The lone wolf attack pattern by terrorist which is performed in different place and time, it is revealed that the suspect is the same person. The term means a support to ideology, group, but it is performed by a single person. This pattern is, generally, committed by a suspect who prefer live alone to belong in a group. They are introvert, they cannot interact emotionally with other people and avoid social interaction. The next pattern is by using women and children as their new method. The pattern is very contrast with previous method which uses young uneducated male person. Nowadays, children and women also contribute in suicidal bombing. The suicidal bombing by three family in Surabaya merge questions among society how could a wife and a mother of children willing to sacrifice his kids. If we look at the mind pattern of the women, they could be more dangerous than male terrorist, they have of what we called single-minded pattern, they ignore another important aspect in order to achieve the goals.

Third, There is no law that regulates the ex terrorist control. About the control over ex terrorist, according to the head of intelligent council of Surabaya jurisdiction, he stated that the new anti terrorism law must include articles that mentioned ex terrorist prisoners. Because, many terrors are being committed from recidivism. The total amount of recidivism is $10 \%$ from all prisoners that now serve in jail for long time. it is important to take a note that those terrorist who are both recidivism and prisoners are marked as heroes and has strong affection in their organization.

The characteristics of ex prisoners who has potential to repeat terrorism action. The following is the causes for these case, there are:

First, the behaviour characteristic of ex prisoners who already served his time in jail. The movement of Intel starts from phenomena to the reality of crime. This means, starting from the potential for disturbances (PG). Then, it is followed by a disturbance threshold (AG) until the existence of a real disturbance $(G N)$ in the form of crime. Similar to these types of activities, namely the PG, AG and GN models, there is also an old term about the nature of threats, namely the Criminologent Correlative Factor (FKK), then what is called Police Hazard $(\mathrm{PH})$, and Factual Threat (AF). Detection in the intelligence function has four types of classification, namely first, $\mathrm{AF}$; second, $\mathrm{PH}$, third, the Criminogen Correlative Factor (FKK); and fourth, loss or victim, which is the result of the emergence of crime. So, these reliable statements answer the strategic role of intelligence in carrying out the main tasks of the National Police, namely from the stage of preceding, accompanying to ending an event. Regarding Potential Disorders (PG) or Correlative Factors of Criminogen (FKK) occupy the initial stage / early detection of intelligence activities which are characterized by the dynamics in the community. The existence of daily activities in the Police of Social and Culture jurisdiction, such as political campaigns, trade, and the occupation of an area by former Terrorism Prisoners with "red notice", is an activity that has the potential to give interference.

The investigation toward ex prisoners is started from report of the track record of the prisoners. The characteristics of prisoners who are labelled with red notice are those who had these behaviours: (a). They still believe in radical ideology. Radicalism could be defined as struggle to do reformation and change by using violation. According to the Indonesia Dictionary, radicalism is an understanding or flow that wants social or political change or renewal in a violent or drastic way; or extreme attitudes in political flow. (Umi Chulsum, 2006: 561). Radicalism in the name of religion is an ideology or behaviour which are spotted with some points such as intolerant, unable to accept another opinion, revolutionary that uses violation to achieve the goals. One of the indicator for the officer to give the red notice label to a prisoner, according to the interview with head of Intelligent council of Surabaya, he stated that there are three levels of the categories which are, as follow: The first level is the most anarchy radical, they are people who are refuse to join meeting with officers and refuse the 
deradicalization program by government; The second level is the ex prisoner who is willing to join the meeting but refuse to follow deradicalization program; The third level is the ex prisoner who is willing to banish his old radical way but refuse to invite other friends. (b) Create riot inside Prison. There are several riots committed by terrorist prisoners which are gathered from East Java Police Department data, they are mentioned below, as follow:

- Lowokwaru prison of Malang occurred on Saturday 8 August 2015, at 10.45 WIB. The prisoners involved in this action are BS Alias BD Alias Pak Dokter, WM alias DDG, FDL alias MS;

- Madiun level I Prison on Thursday of 17 November 2015, at 20.30 WIB. The prisoners involved in this action are: WM alias DDG, AU alias DLH, AA alias HBB;

- Pamekasan level II Prison on Sunday 20 September 2015, The prisoners involved in this action is SM bin ISM;

- Kediri level II Prison on Saturday 02 February 2016, The prisoners involved in this action is $\mathrm{DR}$ bin $\mathrm{AD}$;

- Lumajang level II Prison on Thursday 12 April 2016, The prisoners involved in this action is WGN.

The importance of controlling the terrorist is because their mindset of allowing violation to achieve the goal for those who already free from prison. By the indication, it is very fragile for them to repeat the action because of the state of their mind that has been completely corrupted. (c) The ability to craft bomb. For the prisoners who possessed ability to craft bomb get special control by officer. Because, such kind of skill is very rare and importance in their organisation, the young terrorist may look for them to learn on how to craft a bomb as it is the main weapon of terrorist to commit their crimes.

According to the study by Sarlinto Wirawan, he stated that there is a wrong assumption about the metal characteristics of terrorist. Some of experts stated that some of suicidal bombs and another terror actors are psychopath people. Unfortunately, in previous study, Sarlianto stated that there is no element of Schizophrenic, he concludes that the actors of terror is not people who suffer from psychopath but it is true that they suffer from other mental disability.

According to the interview with the head of intelligent council of Surabaya, it is very important to control these ex prisoners with man to man method in order to perform early detection, the criteria are as follow:

First, Severe Introvert Behaviour. The member of terrorism tends to live among people either in city or at village. But they tend to avoid social interaction and choose to remain silent in public area. The behaviour could be included to anti social behaviour which ignores the existence of other people or general society in his neighbourhood. Theoretically, such kind of behaviour will result in several points, as follow: (a) It disturbs the harmony live within society, it damages social integration between citizens, threaten public order and its safety, spread the mental fear all over society, creates a riot between communities within society, intercepts the nation to be developed. it will be quickly spread if it does not directly overcome. (b) They are not open minded as they think that their organisation is the absolute order. Such kind of anti social will tend to assume that other people is a weak race and in worse case, they think that such kind of weak race must be eliminated.

Second, The Intense communication between ex terrorist prisoners with another affiliation of radical or another terrorist. $\mathrm{AW}$ is a wanted person who commit terror in Pasuruan region in 2010. AW is a recidivism which is being controlled by officers. It is revealed that he still follow and join some radical organisation with another recidivism. In another case, it is revealed that two suicidal bombing suspect in Surabaya ever meet with one of terrorist prisoners in Tulungagung level II Prison. They are known to exchange idea while conducting the meeting, the strategy, or the next command. Thus, it must be labelled as upcoming cases if one prison meet with another and their communication is potential interference within topic of terrorism.

Three, The Continuing Affiliated condition between ex prisoners with radical groups. The need to control former terrorism prisoners, who are still in touch or communicating with several networks of radical organizations, including ISIS, will lead to more radical understanding in the former prisoner. Because, the environmental factors in which he 
establishes a community will theoretically bring about the influence of criminal thinking that continues on criminal acts. According to Moeljanto, the influence of the environment that has surrounded a person for a certain time has an influence on his personality. The dynamic factors that work and influence each other are both inherent and environmental factors. So the good and bad of a person depends also on the environment. For ex-terrorist members, it is not easy to get the environment because of the negative labels already attached to it. Thus, they assume that the only environment or the old community that may serve opportunity and place to gather and interact in a social environment is the old community as primary base.

Fourth. Low Sense of Nationalism. For the follower of radicalism, there is one big way to reveal their character, it is their response to national flag. One of the members does not willing to give respect to the flag, they refused to celebrate national independence day on August $17^{\text {th }}$, they even asked their family and children to follow the doctrine.

Fifth, The situation where community refused to embrace the ex terrorist. According to the head Counter Terrorism Council of Indonesia, Suhardi Alius, the response of society whether to embrace this ex terrorist will determine the repetition of terrorism. He gave a example of bombing terror by Juandha, the church bomber in Samarinda. In his previous record, Juandha is just a support to terrorism, he barely not doing something big. Unfortunately, the society refused to embrace him when he is set free after serving several years in jail. His children and wife are returned to the big family. Eventually, he repeated his action. As also stated by head of Police intelligent stated that the potency of these ex terrorist to commit another terror is very big. They could not return to normal life, because the financial aid during the bombing or Radicalization process are supported by the organization, moreover, the society still unable to embrace the returned ex terrorist in the neighbourhood. The labelling theory is applied to this scenario where society has labelled the ex terrorist as bad person for like forever, these ex terrorist will return to their way to live their life.

\section{CONCLUSION}

The early detection performed by intelligent council is started from planning, seeking, managing, and displaying the information. The obstacles during the operation come from internal and other factors. The internal factors are bad stock of human resource, minimum financial aid, and worse coordination with Densus 88 organisation. Other factors are the pattern of attack which continuously changing such as using children and women as suicidal bomb subject. The last obstacle is that there is no law that regulates the control of ex terrorist prisoner in the new anti terrorism constitution.

The dangerous characteristics behaviour by prisoners that need to be noted are the radical ideology that is not completely banished from their mind. By triggering some riots while in prison is important to be controlled. The ability to craft bomb is very dangerous as another free terrorist will look this as a chance to expand their ability. Next, the people who commit their life to do suicide bombing is concluded that they are not entirely psychopath, but it is the state of blank mind about the doctrine of radicalism. The next conclusion is the characteristic of prisoners who are potential to repeat the action is marked by introvert behaviour, they are still contacting another terrorist both free and served time in jail, they are still affiliated with some radical movements, low sense of nationalism, and the condition which society refused to embrace the returned terrorist in their neighbourhood.

\section{REFERENCES}

1. Kartono.Kartini, Patologi Sosial 2. Grafindo Persada, Jakarta, 2008.

2. Suharsimi Arikunto, Prosedur Penelitian Suatu Pendekatan Praktek, Rineka Cipta, Jakarta, 2002.

3. Susaningtyas Nefo, Komunikasi Dalam Kinerja Intelijen Keamanan, PT. Gramedia Pustaka Utama, Jakarta, 2013.

4. Tamat Suryani, Terorisme dan Deradikalisasi: Pengantar Memahami Fundamentalisme Islam dan Strategi Pencegahan Aksi Terorisme, Jurnal Keamanan Nasional, No. 2, 2017.

5. Thomas Santoso, Teori-Teori Kekerasan, Ghalia Indonesia, UK Petra, Jakarta, 2002. 